\title{
A tribute to Dr. Gordon Hisashi Sato (December 24, 1927-March 31, 2017)
}

\author{
J. Denry Sato ${ }^{1} \cdot$ Tetsuji Okamoto $^{2} \cdot$ David Barnes $^{3} \cdot$ Jun Hayashi $^{4} \cdot$ Ginette Serrero $^{5} \cdot$ Wallace L. McKeehan $^{6}$
}

Received: 27 December 2017 / Accepted: 2 January 2018 / Published online: 12 February 2018 / Editor: Sandra L. Schneider

(C) The Author(s) 2018. This article is an open access publication

\begin{abstract}
Gordon H. Sato, an innovator in mammalian tissue culture and integrated cellular physiology, passed away in 2017. In tribute to Dr. Sato, In Vitro Cellular and Developmental Biology - Animal presents a collection of invited remembrances from six colleagues whose associations with Dr. Sato spanned more than 40 years. Dr. Sato was a past president of the Tissue Culture Association (now the Society for In Vitro Biology), editor-in-chief of In Vitro Cellular and Developmental Biology (1987-1991), and the recipient of the lifetime achievement award from the Society for In Vitro Biology (2002). He was elected to the US National Academy of Sciences in 1984.
\end{abstract}

Keywords Tissue culture $\cdot$ Differentiated cell lines $\cdot$ Serum-free media $\cdot$ Cellular endocrinology $\cdot$ Manzanar project $\cdot$ Mangrove trees

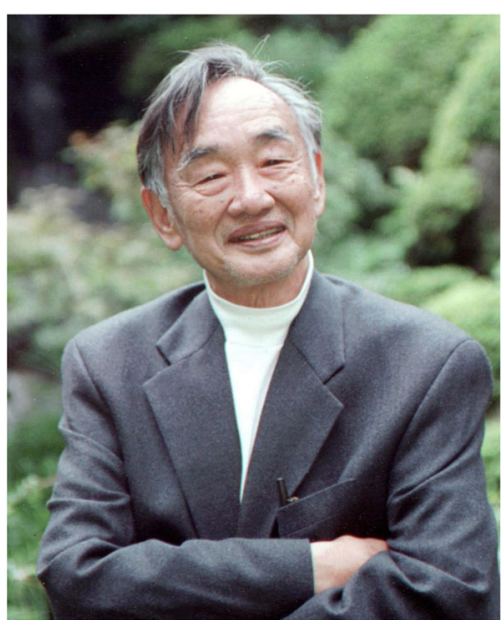

Dr. Gordon Hisashi Sato (December 24, 1927-March 31, 2017)

Tetsuji Okamoto

tetsuok@hiroshima-u.ac.jp

J. Denry Sato

denrysato@aol.com

David Barnes

davidbarnes945@gmail.com

Jun Hayashi

jhayashi@precisionantibody.com

Ginette Serrero

gserrero@agpharma.com

Wallace L. McKeehan

wlmckeeh@swbell.net

\section{The Golden Era of Gordon H. Sato's Scientific Career: Brandeis University and UC San Diego (1958-1983) by J. Denry Sato and Tetsuji Okamoto}

Gordon Sato received his Ph.D in Biophysics with Max Delbruck at Caltech in 1955 where he was Delbruck's last phage student. The title of his Ph.D thesis was "The Effect of Urea on Cofactor Requiring Bacteriophage" (Sato 1956). He then did postdoctoral stints with Gunther Stent at UC Berkeley and with Theodore Puck at the University of Colorado Medical Center where he overlapped with Dick Ham. Puck was interested in adapting the quantitative analytical techniques developed by phage biologists to studies of mammalian cells in culture. Gordon's first studies on mammalian cell culture focused on the growth requirements of

1 Manzanar Project Foundation, 27 Cedar St., Wenham, MA 01984, USA

2 Department of Molecular Oral Medicine \& Maxillofacial Surgery, Graduate School of Biomedical \& Health Sciences, Hiroshima University, Hiroshima 734-8553, Japan

3 School of Science and Technology, Georgia Gwinnett College, Lawrenceville, GA 30043, USA

4 Precision Antibody Inc., Columbia, MD 21045, USA

5 A\&G Pharmaceutical Inc., Columbia, MD 21045, USA

6 Center for Translational Cancer Research, Institute of Biosciences and Technology, Texas A\&M Health Science Center, Houston, TX 77030, USA 
HeLa cells (Sato et al. 1957; Fisher et al. 1958, 1959). This interest in mammalian cell growth requirements and mammalian cell physiology would continue for the rest of his scientific career. In 1958, Gordon was recruited by Nathan Kaplan and Martin Kamen to join the faculty of the Graduate Department of Biochemistry at Brandeis University. In our opinion, this appointment started the 25-yr "golden era" of Gordon's scientific career, which would last through his tenure at the Department of Biology and the Cancer Center at UC San Diego.

At Brandeis, Gordon and his colleagues made several significant advances in the field of mammalian tissue culture. First, they discovered that the commonly observed phenomenon of "de-differentiation" of mammalian cells in culture was actually the overgrowth of differentiated cell types by fibroblasts (Sato et al. 1960). Armed with this insight, the Sato lab devised a protocol for selecting differentiated tumor cells that were able to survive and proliferate in culture; this protocol consisted of multiple cycles of alternately passaging tumor cells in vivo and in vitro. Using this approach, they isolated continuous mammalian cell lines from rodent endocrine tumors provided by Jacob Furth (Buonassisi et al. 1962; Stollar et al. 1964; Yasumura et al. 1966; Tashjian et al. 1968; Cuprak and Sato 1968) and cell lines from other differentiated tissues (Mohit and Sato 1967; Benda et al. 1968; Augusti-Tocco and Sato 1969; Rosenthal et al. 1970). These cell lines were the first to exhibit differentiated traits of their tissues of origin (Sato et al. 1970).

In 1969, Gordon joined the Department of Biology at the University of California at San Diego. At UCSD, Gordon began investigating the role of animal serum in mammalian tissue culture media because a postdoc observed that ovarian cells would not respond to trophic hormones in serum-supplemented medium even though they would respond if transplanted in vivo. However, ovarian cells would respond to exogenous gonadotrophins in medium containing charcoal-extracted serum. In one approach, the Sato lab undertook to isolate novel trophic factors from serum and other biological fluids. One of the results of these efforts was the discovery of fibroblast growth factor (FGF-2/basic FGF), which was originally called ovarian growth factor (OGF). FGF/OGF was initially discovered as a contaminant in preparations of luteinizing hormone and later was found in bovine pituitary glands (Gospodarowicz et al. 1974; Nishikawa et al. 1975). FGF was the fourth hormone-like polypeptide growth factor to be discovered after nerve growth factor (NGF), epidermal growth factor (EGF), and insulin-like growth factor (IGF-1)/somatomedin C.

In a second approach to deciphering the role of serum in tissue culture medium, the Sato lab undertook to replace serum in culture media with purified hormones and growth factors. This line of thought and experimentation led to the seminal work by Hayashi and Sato (Hayashi and Sato 1976) demonstrating that mammalian cell lines could be maintained and propagated in defined media containing hormones and growth factors in place of serum. This report had two sustained effects on tissue culture research: it altered the way in which researchers thought about cell culture and stimulated the widespread development of serum-free hormone-supplemented media for a variety of cell types by the Sato lab and others (Barnes and Sato 1980, 1981); and, it stimulated the search for novel growth factors with autocrine or paracrine activities by offering an assay system for novel factors. This research validated the use of in vitro cell culture as a way to study tissue interactions at the cellular and molecular levels, which Gordon referred to as the field of "cellular endocrinology" (Barnes et al. 1987). This work also predicted that any cell type that had the potential to grow could be propagated in a defined hormone-supplemented serum-free medium.

Gordon's experience studying normal and malignant cell proliferation in vitro suggested to him that agents that blocked growth stimulatory signals could be used as cancer therapeutics, and he thought monoclonal antibodies to hormone and growth factor receptors could fulfill that function with a high degree of specificity (Sato 1981). The Sato lab along with Gordon's collaborator John Mendelsohn provided the proof of principle experiments for this idea by demonstrating that neutralizing monoclonal antibodies to the human EGF receptor inhibited tumor cell proliferation in vitro (Sato et al. 1983) and inhibited the growth of tumor xenografts in nude mice (Masui et al. 1984). It is noteworthy that this work preceded by $6 \mathrm{yr}$ the development the antibody that became trastuzumab (Herceptin), which was the first antibody targeting a signaling pathway to be approved by the FDA to treat cancer. A chimeric version of the monoclonal antibody 225 (Erbitux/cetuximab) was subjected to clinical trials and approved by the US Food and Drug Administration to treat advanced colon cancer (2004) and head and neck cancer (2006). Erbitux is currently approved for use as a cancer therapeutic in over 80 countries. Gordon also started the Manzanar project at UCSD by isolating heat-stable algae that could be used to feed fish (Shinohara et al. 1984); over the subsequent $20 \mathrm{yr}$, the project demonstrated the value of using mangrove trees as livestock fodder in arid land bordering oceans where conventional agriculture was impractical.

In 1983, Gordon became the Director of the W. Alton Jones Cell Science Center, a not-for-profit research institute in Lake Placid, NY. Although he remained scientifically productive, the focus of his career changed from scientific research to supporting and promoting the careers of young scientists and students. Thus, the "golden era" of his own scientific career came to an end. In 1986, Gordon became a scientific entrepreneur by starting the biological reagents company Upstate Biotechnology (UBI) as a subsidiary of the Cell Science Center; 20 yr later, UBI was sold for \$215 million.

Gordon received a number of awards for his scientific achievements. In 1981, he shared Brandeis University's 
Rosenstiel Award for Distinguished Work in Basic Medical Research with the future Nobel laureates Stanley Cohen and Rita Levi-Montalcini. In 1984, he was elected to the National Academy of Sciences for his work in cell biology. Gordon received three awards for the Manzanar Project for sustainable food production: the Rolex Award for Enterprise in 2002, the Lifetime Achievement Award from the Society for In Vitro Biology in 2002, and the Asahi Glass Foundation Blue Planet Prize in 2005. In 2005, he was also given the Distinguished Alumni Award by the California Institute of Technology.

\section{Thoughts on Gordon Sato by David Barnes}

Much of Gordon's history has been covered in other articles in this issue: his years on Terminal Island and the Manzanzar Internment Camp, for instance. I will not try to cover those areas. Instead, I will try here to fill in some gaps that I think illustrate the life and temperament of this remarkable man.

All was not entirely bleak through those years at Manzanar. For instance, Gordon played saxophone as a member of the "Jive Bombers," a dance band organized among the camp members. Each internment camp boasted a band, and the Jive Bombers were recognized as the best of them all. Striking photos of the camp, including photos of the Jive Bombers, were taken by Ansel Adams, a friend of the camp Director. Gordon later commented that he was strongly impressed by the ability to grow food crops in the Manzanar desert, and this led to his concept of the Manzanar Project, discussed below.

I first met Gordon when I was a graduate student in 1975. At that time, I was working under Sidney Colowick at Vanderbilt in a loose collaboration with Stanley Cohen on effects of epidermal growth factor on membrane transport. Sidney and Gordon were old friends from days spent together at the Cold Spring Harbor Laboratory. Sidney arranged for us to meet and discuss science, since he knew of Gordon's struggle at the time with serum-free medium and growth factors. To my surprise, Gordon had just visited a catfish farm in Arkansas, and all he could think about was catfish, an indication of things to come with the Manzanar Project, I suppose. When I told him of an inbred strain of catfish that I was aware of, he became quite excited. Although, he never followed up on this idea, Bill Clem at the University of Mississippi did go on to use the system to make significant advances in immunology.

The next time I met Gordon, I was a student in a course in cell culture at Cold Spring Harbor Laboratory taught by Gordon and Hayden Coon. Coon was a friend of Gordon's from his days at Brandies who was something of a cult figure in cell culture, growing cells no one else even thought of attempting. I remember my first glimpse of Gordon at Cold Spring Harbor. At a time when he probably should have been teaching the course, he was outside digging worms to feed a baby bird his youngest daughter, Amy, had found. Science did abound there, however, as James Watson was the Director. Nobel Prize-winner Barbara McClintock lived on the grounds, for instance, and Gordon often consulted with her. Later, I taught the Cold Spring Harbor cell culture course for several years with Gordon and had the opportunity to observe his interactions first-hand. I was most impressed with his ability to abandon details to others (including me), allowing them valuable problem-solving experience and freeing him to think creatively.

I should mention a few things that I learned about Gordon's graduate school history. As Gordon told the story, his introduction to graduate school was an accident. He received a degree from USC in biochemistry, but his grades were not outstanding, largely because he worked during his college days, putting himself through school. Japanese were not popular at the time, and Gordon found work as a gardener, an occupation that should not be surprising to those who knew him. One day, he fell off the truck and injured his ankle so that he could not work. His father told him that he must find a job. Gordon wandered into Caltech and looked at the list of faculty. The first person he approached was George Beadle, later Nobel Prize winner. When Beadle heard Gordon was interested in biophysics, he suggested a physicist in the institution who was then working in biology. That was Max Delbruck.

Max arranged for Gordon to return the next day for an examination from members of the laboratory to determine if he would fit in. The questions covered everything from simultaneous differential equations to entomology. Gordon was accepted. He would later describe the mathematics and physics courses at Caltech as "brutal." In a moment of reflection, he told me that the experience that led him to be accepted in Delbruck's lab taught him that he could "think on my feet." This may be why Gordon could walk into almost any situation with a seemingly minimum of preparation and perform brilliantly. In addition to Delbruck's Nobel Prize, among the other members of the laboratory were Nobel Prize winners James Watson, Niels Jerne, and Renato Dulbecco. Gunther Stent, one of the originators of phage molecular biology, and George Streisinger, originator of the now immensely popular zebrafish model of diploid genetics, were also members of the laboratory, as was, for a time, Nobel Prize-winning physicist Richard Feynman.

Gordon told me that he had no idea that he was in such a remarkable group; he thought every lab had such talent. When Max left for Europe for an extended stay, Watson took over supervising Gordon's Ph.D. thesis. This work, on urea activation of bacteriophage, now is recognized in introductory textbooks as the first clear link between genetics and biochemistry. The work was published in Science with Gordon as the sole author. 
After his postdocs with Gunther and Ted Puck, which are discussed elsewhere, Dr. Nate Kaplan, a close collaborator with Sidney Colowick, took a chance and hired the budding cell biologist, Gordon, in the remarkable hard-core Biochemistry Department the Nate was building at Brandeis. There, Gordon was a leader of an intellectual powerhouse, debunking "de-differentiation in vitro," for instance, and developing prototype cell cultures that now have been used as models for decades. Some of these cell types, in fact, carry out their functions better in vitro than in vivo. In addition to his compatriots in the department, Gordon also was close to other faculty members, notably Maurice and Raquel Sussman. Maurice was instrumental in establishing the Dictyostelium system for studying differentiation, and Raquel made major contributions in the area of repair mechanisms in yeast. Gordon said that he learned from Maurice "Sussman's Third Law of Embryology," which is "For every observation there's an equal and opposite observation." Much of Gordon's successes at Brandeis are well documented elsewhere in this issue. When Nate moved to San Diego, Gordon moved also: the beginning of another highly fruitful period in his career.

With this introduction, I pursued a postdoc in Gordon's lab in San Diego starting in 1977. From his postdoctoral days with Puck, Gordon had been interested in the components of serum that stimulate cell growth in vitro, and Izumi Hayashi had just published the seminal paper on serum-free cell culture with $\mathrm{GH}_{3}$ cells (a cell line originally developed by Gordon at Brandeis). The laboratory was intellectually ripe. Gordon had been criticized regarding the $\mathrm{GH}_{3}$ paper. It was asserted that the work was a fluke that could not be repeated with other cell types. He set about dealing with this by suggesting that each postdoc in the lab choose a different cell type and develop a serum-free formulation for it. The results were spectacular. It should be pointed out that a critical contribution to the results was the development by postdoc Jennie Mather of the now-ubiquitous "F12-DME" (or: "DME-F12") medium. That Jennie was responsible for this has largely faded into classical memory.

Many non-science endeavors went on at that time, as well, such as the garden Gordon had us build on the roof of the laboratory, which almost brought the roof down when we added the extra weight of watering it, or the instillation of air conditioners in the hot San Diego weather. These were installed inside the labs, with the side that normally would have faced outside a window facing the inner utility corridor. In a short time, condensate from the air conditioners falling into the utility corridor shorted out the electricity for the entire area.

A famous tale from the lab at the beginning of that period is the "blood meal" story. Gordon was aware that many important factors critical to serum-free formulations were to be found in blood, and used his wits to derive a method to isolate them. He was familiar with blood meal, a blood-derived by- product of bovine slaughter houses, as a fertilizer. He set about a "high-volume," "low-tech" approach to isolating such factors. Blood meal was delivered in large bags, and batch chromatography carried out in garbage can-sized containers, stirring with broomsticks. Washes were accomplished by first hoisting the sediment out of the containers in blankets for exposure to the washes. The blood meal, itself, stunk, and the prep area soon took on a similar smell. Buzzards circled overhead. Although this procedure was successful; enough of some factors were isolated to last for years in cell culture experiments, it soon became unnecessary upon the availability of purified, recombinant DNA-derived factors.

There is much more that can be said about the period at UCSD, such as the work detailed elsewhere on antibody to the EGF receptor, but much of it is beyond me, as I was leaving for my first faculty position at the time of the beginning of that work. However, since much of the technical detail of serumfree medium has been co-opted by industry by now, I think it is important to emphasize Gordon's original motives. In his words: "I have also been of the opinion that working out the hormonal requirements, and responses of each individual cell type will lead to a deeper understanding of integrated physiology." These goals still have much to offer biology and will further influence Gordon's reputation as time and research proceed.

Finally, I will discuss some aspects of the Manzanar Project. This monumental endeavor started with a simple idea. One evening, Gordon and I were sitting on the balcony of the laboratory, a converted Marine barracks, smoking cigarettes, and sharing a bottle of wine. We were watching a most unusual scene. This was the time of the first of several "gas shortages" of the late 1970s, and we could see a gas station over a hill with cars lined up for half a mile, hoping to fill their tanks. Gordon mentioned that he had just come from a seminar in which he had learned that some types of algae contained as much as $50 \%$ lipid, and, in his brilliant way, wondered aloud if this might provide a renewable replacement for gasoline. Gordon sets up cultures of algae. Initial attempts at this idea failed, primarily because of contamination from unwanted algal species. Then, Gordon added his second brilliant idea: use algae from desert hot springs, essentially creating a protected monoculture. He sets up a prototype alga farm in ponds dug on the shores of the Salton Sea in the California desert, overseen by Penny Roberts. Some misadventures followed. For instance, in order to protect the algae from natural predators (primarily small flies), the large-scale alga cultures were encased in plastic. Unfortunately, these acted as huge balloons and floated into the Salton Sea, leading the Navy based in the area to react harshly.

The algae were supplied by Kazuki Shinohara, who had just arrived in Gordon's lab to learn cell culture. Gordon immediately sent Kazuki to hot springs in the Anza Borrego desert to collect algal samples. Kazuki initially was totally 
bewildered by this but later became an essential scientist in the project. Kazuki's visit, by the way, is an example of many of Gordon's contacts with Japanese scientists, whom he supported in the firm belief that Japan could become a powerhouse of innovative science if attitudes toward successful science there could change. For instance, Gordon strongly supported the Japanese Association for Animal Cell Technology, established by Hiroki Murakami, a former sabbatical visitor in his lab and a forward, original thinker.

Gordon left for Lake Placid soon after I left the lab, so there is little I can say about the experiences at the Cell Science Center or with the Upstate Biotechnology company. These are covered well elsewhere in this issue. I am, however, familiar with the "Manzanar Project," which proceeded through that time and well after Gordon retired as the Director of the Cell Science Center. The project was, of course, named after the internment camp he inhabited during World War II. Gordon saw there that food could be grown in the desert, with the proper thought to the project, and set about his own unique approach.

Gordon carried his alga-based idea of the Manzanar Project to several continents and finally settled on Eritrea on the east coast of Africa. Unfortunately, Eritrea was involved in a dangerous war of independence from Ethiopia at the time, but this did not stop Gordon. He visited many times and pressed for the success of his project. He brought on my wife, Emily, as the Development Officer, and we had much to do. As the work with algae progressed, Gordon had the idea that he could convert microorganisms into edible meat by feeding the algae to brine shrimp and then feeding the brine shrimp to fish. $\mathrm{He}$ used tilapia, a native fish of Africa, feeding them brine shrimp grown on algae present in salt water ponds dug along the desert shore of the Red Sea, and was quite successful at this venture. Gordon was clearly thinking of the science of ecosystems at that time: from oil to algae to brine shrimp to fish. The goal was to provide food in areas of barren, desert seacoast where people were starving, a major part of the world.

At this point, Gordon made another of his lightening insights. He noticed that the desert, largely devoid of trees, showed greenery at the rare points where fresh water entered the Red Sea. He examined what was special about the chemistry of the area and established that the mangrove trees growing there required iron, nitrogen, and phosphorus, which were limited in the ocean but were supplied by the fresh water. The mangrove swamps provided vegetation for animals (both leaves and seeds) and also created a protected environment for sea creatures. He quickly devised a "low tech" means for supplying the necessary nutrients to the trees, using iron pipes and plastic bags of nitrogen/phosphorus manipulated so that the nutrients were delivered to the trees slowly. Then, seedlings were planted on a large scale and success was rapid. He told me at one point that his reason for success in the project was "perseverance," but I think it was much more than that (Fig. 1).

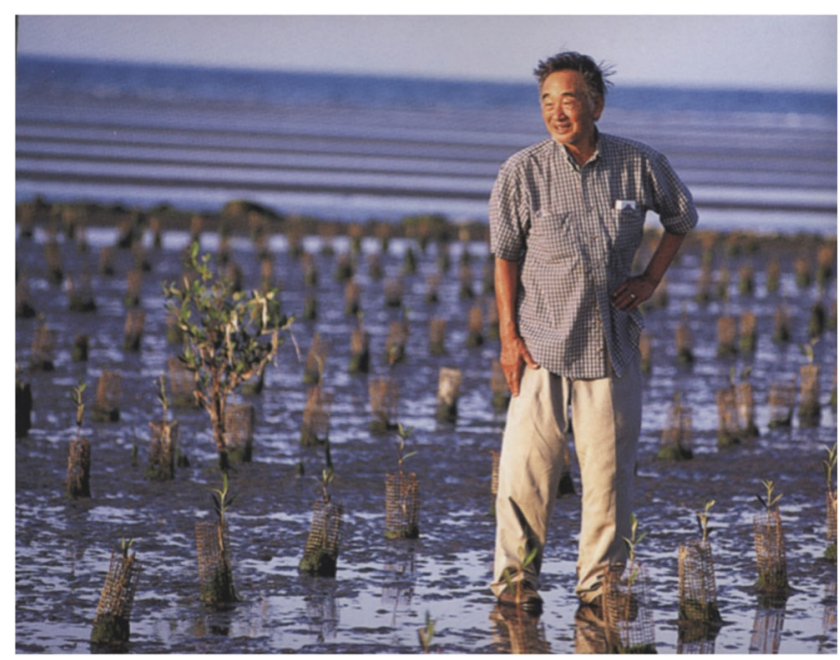

Figure 1. Gordon among recently planted mangrove seedlings.

I was lucky enough to accompany Gordon to Eritrea, and Morocco as well, and was amazed at the success this simple approach had accomplished at quickly producing mangrove forests (Fig. 2). These swamps provided vegetation for local sheep and goats and a habitat for indigenous aquatic animals. The prototype work was mostly carried out by women in a small Eritrean village near Massawa (Hargigo), and Gordon made sure they were fed properly and began to teach them to read, as well. At one point, Gordon set about providing funds to the villagers to allow them to buy, and then care for, their own sheep. This became a little complicated. The first issue was obtaining local currency at a reasonable price, the exchange rate for which was controlled by the government. Then, there was the issue of providing the money to the villagers, who spoke Oromo, a primary language in Ethiopia, and explaining the intent of making the money available. The major language in Eritrea was Tigrinya. Gordon actually had learned to speak the latter language rather well but did not want to create any confusion. So, we traveled to Hargigo with the money and several interpreters. The villagers were gathered together, and Gordon began to explain to them that he had brought them money to buy their own animals. This was accomplished in the following way: Gordon spoke English, which was translated into Tigrinya by a native Eritrean who understood English fairly well. Then, another translator who spoke both Tigrinya and Oromo translated Gordon's words into Oromo by way of the first interpreter. I do not know what the villagers were told or understood, but they did understand that Gordon was continuing to improve their lives, and were clearly grateful.

For his work with mangroves, Gordon received the Rolex and Blue Planet Awards, the latter considered the "Nobel prize for ecology." There are many other stories that could be told, such as Gordon's short-term AWOL near Kobe in order for him to leave his military position to visit his grandmother on 
Figure 2. Mature mangrove forest in Eritrea.

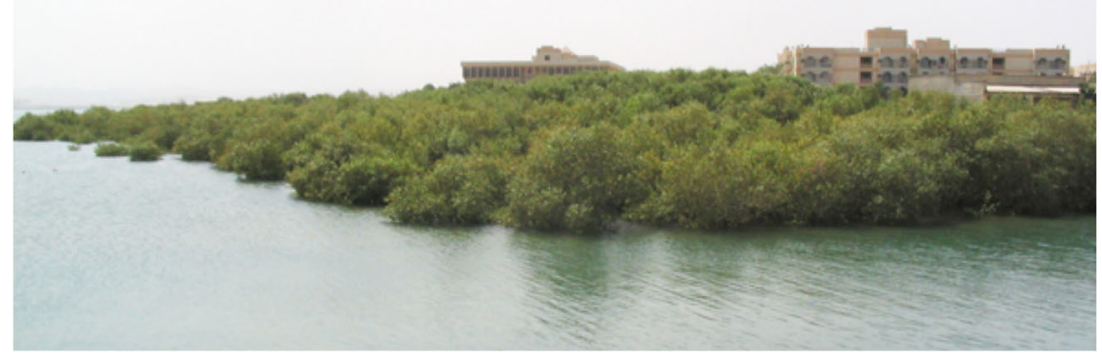

the main Japanese island, but space here is limited. I hope in this article, I have given some impression of this extraordinary man, not just Gordon's courage, intelligence, imagination, and gift for working with people but, most importantly, his humanity and enormous care for the people of the world, wherever they may be. He was my friend and mentor for $40 \mathrm{yr}$ and a profound influence on my wife and me that will never change. I know this is true for many others, as well (Fig. 3).

\section{Memories of Gordon Sato by Jun Hayashi}

There is a consistent line of thought throughout Gordon's scientific career. My guess is that this was formed during his graduate years at Caltech working with Max Delbruck where Gordon witnessed the birth of molecular biology. The success and the generation of explosive knowledge of genetics were based on the simple fact that bacteria could be grown in a completely defined media and the discovery of auxotroph

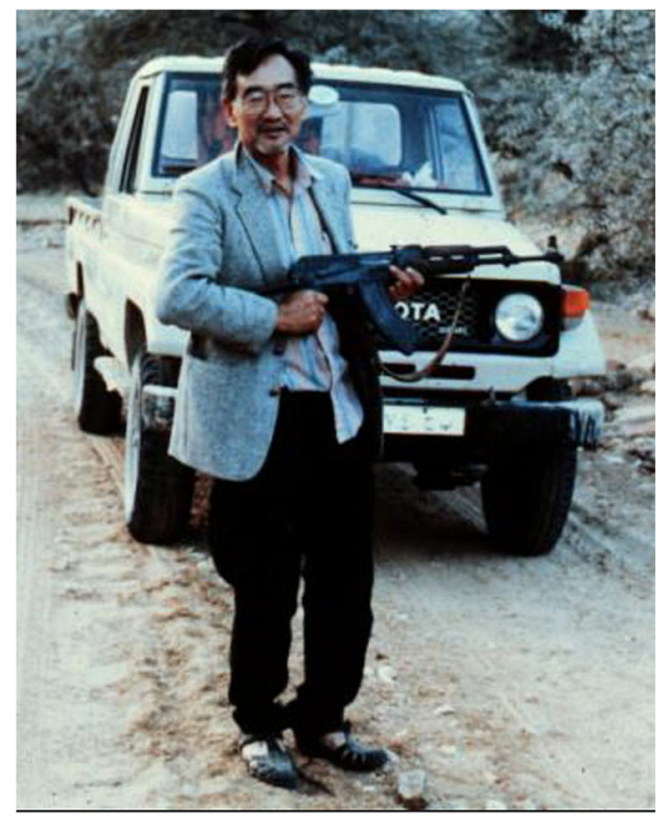

Figure 3. Hunting for lunch in the East African Desert. mutations that paved the foundation of modern molecular biology. If you follow Gordon's publications, it was about growing cells in defined media. Gordon must have thought that just as it was possible to grow bacteria in a chemically defined media, growth of mammalian cells in defined medium could shed light on the foundation of life. As we all know, his intuition was correct. Dulbecco was at Caltech at the time he was a graduate student and he must have also influenced his thoughts. Gordon once told me that when he asked for career guidance to Max, he told Gordon, "You are not smart enough to make it in biophysics. There is a new field called cell biology. Go see Ted Puck in Colorado." After spending 1 yr in Gunther Stent's laboratory at UC Berkeley, he moved to Ted Puck's laboratory at the University of Colorado in Denver.

In 1957, my father received a fellowship from Rockefeller foundation to spend $2 \mathrm{yr}$ in the USA for sabbatical to work in the laboratory of Heinz Herrmann at the University of Colorado in Denver. This is when my father became acquainted with Gordon and Sato family. In 1958, Gordon moved to Brandies University to join the Department of Biochemistry headed by Nate Kaplan. In that same year, Heinz Herrmann moved to the University of Connecticut and consequently the Hayashi family moved to Connecticut as well. Due to close proximity, Gordon often came to Storrs to bring us back to Waltham to spend a weekend with his family. He had a big station wagon and along the way back to Boston, he would spot wild burdock (gobo) growing beside the road and he would stop, take out a shovel from his car, and start digging. I helped him dig out few burdocks. Kinpira gobo was one of his favorite foods. To this day, every time I spot a wild burdock growing, it reminds me of Gordon.

After $2 \mathrm{yr}$ of sabbatical, the Hayashi family returned to Japan, and our interaction with the Sato family was mostly limited to exchange of Christmas cards. After my sister graduated from college in Tokyo, my father encouraged her to go to the USA for graduate education. By that time, Gordon was at UCSD. My sister applied to UConn and to UCSD and was admitted to UCSD but rejected by UConn. When my turn came to attend graduate school, I also applied to UConn and UCSD and I was admitted to UConn but rejected by UCSD. In the summer of 1975, I visited my sister in San Diego and 
worked in Gordon's lab helping my sister plating hundreds of 35-mm dishes with $\mathrm{GH}_{3}$ cells in F-12 medium containing many hormones and factors. I used to see Gordon sitting in front of the Edge Guard hood culturing cells while smoking his pipe. That very Edge Guard hood is still working in our company A\&G Pharmaceutical, Inc.!

In 1975, sterilization of culture media was carried out using Coors ceramic candles. Unlike other beers, Coors beer was not pasteurized but rather filtered using ceramic filters to remove live yeast from the fermentation tank; hence, the same filter was used to sterilize media. It looked like a candle so it was called candle filter. When a brand new candle filter was used for serum-containing medium sterilization, Gordon observed that cells did not grow very well compared to the same medium sterilized using the candle filter that has been used several times. This was the first observation to suggest that new ceramic candle was removing some factor required for cell growth from the serum, and this was the beginning of the concept that serum contained "growth factors" that were important for cell growth. So the effort to replace serum with hormones and factors available then got started.

An eye-opening discovery that contradicted the classical endocrinology concept was the fact that many of the hormones were discovered to have growth-promoting effects on many cells. The trophic hormones such as LH, LHRH, FSH, ACTH, and prolactin were believed to act only on target cells. When some of these hormones were shown to exhibit growth promoting effects on many off target cells, it was hard for classical endocrinologists and cell biologists to swallow the fact and accept an emerging concept that different types of cells require different sets of hormones and growth factors for their growth. Studies coming out of Gordon's lab showed that not only it was possible to grow cells in a completely defined medium, but the growth requirements differed from cell type to cell type. With a defined medium optimized for the growth of hepatocytes for example, it was possible to selectively grow functional hepatocytes devoid of contaminating fibroblasts in primary culture. This finding must have been especially satisfying to Gordon since while he was a junior faculty at Brandeis, he wrote a grant to the American Cancer Society showing in his preliminary results his observation that functional hepatocytes could be cultured. One of the reviewers, then a prominent scientist, wrote to Gordon indicating that Gordon should spend more time looking at the cells under the microscope, and if he did, he would find without doubt that hepatocytes dedifferentiate into fibroblasts and that differentiated cells cannot be grown in vitro. He was told not to ever apply for grant support from the ACS.

Through the use of defined media, Gordon helped stimulate the discovery of many growth factors, such as FGF, and PDGF and IGF-I by others. Since growth factors played an important role in cancer cell growth, it was natural for him to deduce that neutralizing antibody to growth factor receptor should block the growth of cells that critically required the growth factor for their growth. Denry Sato and Tomoyuki Kawamoto in Gordon's lab developed neutralizing antibodies to EGFR that later were developed into therapeutic antibody Erbitux.

Being in Gordon's lab was an interesting experience. He would ask what you are interested in and may suggest a topic to work on, but after that, you were on your own. He never dictated to you what to do. He expected you to think. When he was a postdoc with Ted Puck, Ted would write what he wanted people to do each day on a piece of paper and put it in everyone's mail box. Gordon would put his note back into Ted's mail box. After a while, Ted asked Gordon why he returned the notes, and Gordon answered "I have my Ph.D. and I know how to think". From that day on, Ted stopped sending him notes.

Although there were numerous postdocs in his lab, Gordon did not produce many graduate students. I just know of his San Diego era but I only know two graduate students that came out of Gordon's lab. One was my sister Izumi and the other was Henry Fong. My sister used to write lengthy letter describing how tough Gordon was at his lab meetings. She shed many tears and questioned herself whether she was fit to become a scientist.

When I joined his lab in 1982, Gordon's interest was in algae (Fig. 4). Gordon used to organize a lab picnic in the Anza Borrego desert. There, he found a puddle of water with green algae growing covered with a film of oil. He brought back a sample of this water and under the microscope, he saw spirulina filled with lipid droplets. This was the start of his Manzanar Project.

Gordon once told me "I am not interested in WHY. I am interested in HOW." He was interested in solving problems. His interest grew beyond the limits of petri dish and expanded

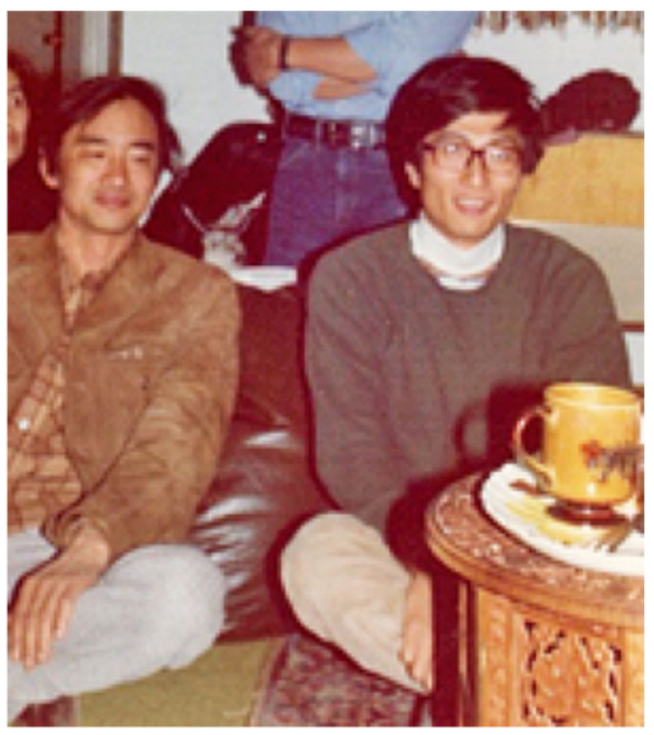

Figure 4. Jun Hayashi with Gordon Sato (1982). 
into solving larger problems. His approach was always simple and effective. He was a true entrepreneur. We were fortunate to interact with Gordon until his death. Gordon served as a chairman of the board of $A \& G$ Pharmaceutical, a company we founded based on Ginette's discovery of PCDGF and my monoclonal antibody development technology. Both Ginette and I owe Gordon a debt of gratitude for his unconditional support. He was a person we looked up to and the person we use as a reference in making decisions. In addition to my parents, Gordon had an irrevocable influence in my life, and I do not feel he is dead. He is alive and well in my heart.

\section{Inspirations from Having Worked with Gordon Sato by Ginette Serrero}

"Don't only practice your art but force your way into its secrets." Ludwig Van Beethoven

Gordon Sato has been and, even though he is gone, remains my mentor, scientific guide, and role model, and he was the person who shaped my professional life into who I am as a Scientist and what I have achieved and am achieving today. I am a strong believer of serendipity, and my story of meeting and working with Gordon Sato is definitely a great example of serendipity. I did my graduate studies at the University of Nice in a lipid biochemistry laboratory, purifying intestinal lipase, and as such I was trained as a lipid biochemist. Looking at the intestine starting material got me interested in cellular differentiation. I was puzzled by how these undifferentiated cells would migrate from the crypt to the villi and became functional cells in the process. In fact, I was wondering what factors could control such a highly regulated process which, when disrupted, would lead to cancer, a disease of differentiation.

I was reading the literature and I stumbled upon a Nature paper by Izumi Hayashi and Gordon Sato talking about defined medium and demonstrating that serum in cell culture medium of pituitary cells $\mathrm{GH}_{3}$ could be replaced by hormones and growth factors able to support cell growth and differentiation. I was not a cell biologist and knew nothing about cell culture and cell biology, but I thought that this was revolutionary and that if one could culture cells in a defined environment, then one could look for differentiation factors. I wished I could learn cell culture. And then two unbelievable circumstances happened, the serendipity events. One is that the director of my institute suggested that I apply for a fellowship to study abroad. The second was that Francois Cuzin from the Pasteur Institute who was visiting my laboratory in Nice mentioned that he knew Gordon Sato and suggested that I go there with my fellowship. He contacted Gordon who, not knowing any better, accepted me to be a visiting scientist in his lab under a French Scientific fellowship.
I will never forget my first meeting with Gordon at the University of California San Diego. He was sitting in his office in Matthews's campus lab, staring at an aquarium, drawing on his pipe, then scrutinizing me, saying nothing for a while until he turned to me and said "what would you like to do?" It was not easy at first. Gordon's laboratory was a tough place to be, particularly when coming from a sheltered and controlling environment like a laboratory in the South of France, but it was also fascinating and a tremendous opportunity for a young woman scientist. Gordon was the ultimate feminist as he wanted to have all the female scientists studying in his laboratory to be smart and successful. It was a difficult work. With not much in the way of reagents, serum-free cell culture was moving by fits and starts, but it was exhilarating and crazy in some ways. Some other labs at the UCSD Biology Department called it "Voodoo Science." Gordon's laboratory looked in some ways to be a type of survival of the fittest, learning cell culture and developing defined media in challenging conditions (remember at that time there were no commercially available growth factors in little bottles), finding one's research niche, and dealing with so many people, so many individualities, so many personalities, and so many ideas (Fig. 5). But at the same time, this environment resulted in forging great ideas, in creating enthusiasm for exploring new biological paths, in creating great bonds and camaraderie that would last a lifetime, and in making you resilient. All of this is due to Gordon, his visionary approach to research, and his determination and unique ways to approach the most difficult questions that the laboratory was tackling. In fact, being from Gordon's laboratory was like wearing a special badge of honor, getting an instant recognition that made you being part of a special family that spanned many generations and many continents. This was all due to Gordon. He enriched the science by his insights, his vision, and his mastery of distilling the most difficult undertakings to very simple steps. This was true for defined media, the development of the anti-EGR receptor antibody, and the Manzanar Project. Gordon was simply brilliant. He would share his enthusiasm

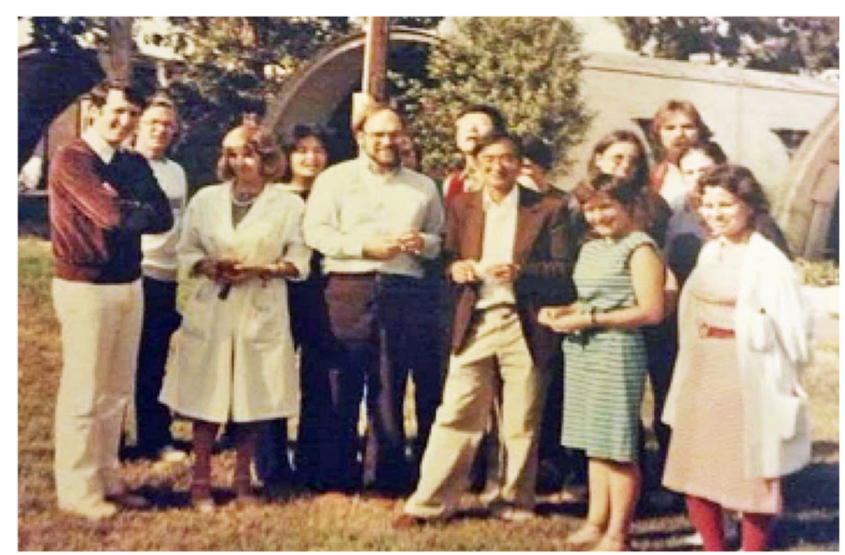

Figure 5. Sato lab personnel at UCSD (1983). 
and provide endless encouragement, if he thought that you were moving in the right direction. He also maintained for all of us a family atmosphere, cultivating friendship and esprit de corps with his communal and legendary fried rice cooked on a hot plate, or by bringing ears of corn to be steamed in the microwave, or bicycle rides in the Anza Borrego Desert. He also showed his care and generosity by bringing the lonely scientists back home. Everybody was working hard. Gordon liked to stay around, talking about science and life and repeatedly listening to the Pachelbel Canon.

But while studying in Gordon's lab was a life-turning moment, it was also tough going. Although generous and encouraging, Gordon was also demanding. He had no patience for the French Philosophical Doubt. It was definitely UnAmerican and Un-Gordon. He had a dim view of lack of common sense and lack of observation and for dumb thoughts, and he would let people know that. At the same time, he was genuinely interested and invested in seeing his students and postdocs succeed, and he was very proud when they did. My lifelong quest for autocrine growth factors that led to the discovery of GP88/Progranulin was all driven by his teaching, his inspiration, and his view of the importance of growth factors on cell growth and survival regulations. I will always be grateful.

For me, Gordon has been a most generous person, traveling to France to lobby my boss into letting me stay one more year at UCSD, offering me a position at the W. Alton Jones Cell Science Center in Lake Placid, giving me the chance to start my own independent laboratory, an opportunity that would never have happened to a female scientist in the South of France at that time, being the inspiration for leaving Academia (in spite of my being a full professor at the University of Maryland), and encouraging me to start a biotech company. He was the seed investor in A\&G Pharmaceutical, and he served on A\&G's Board of Directors providing continued advice, encouragement, and investments. I learned from Gordon's perseverance and tenacity and to "never take NO for an answer" and to always strive for the best, all very useful attributes when dealing with $\mathrm{NIH}$ study sections or venture capitalists.

On a personal level, Gordon opened his house for Jun's and my wedding, and he played the saxophone at the reception. He served as our daughter Sarah's honorary grandfather explaining to her the joy of Nature and Science and life curiosity (Fig. 6). When I arrived in San Diego many years ago, I would never have dreamed any of this, and it was all facilitated by Gordon's nurturing nature.

The rest is history. The ATCC catalog is rich in cell lines developed by Gordon's lab. All the therapeutic proteins worldwide are manufactured in bioreactors in defined media because Gordon's laboratory showed that it was possible. The discovery of many therapeutic antibodies used today in oncology standard care has been facilitated because Gordon's

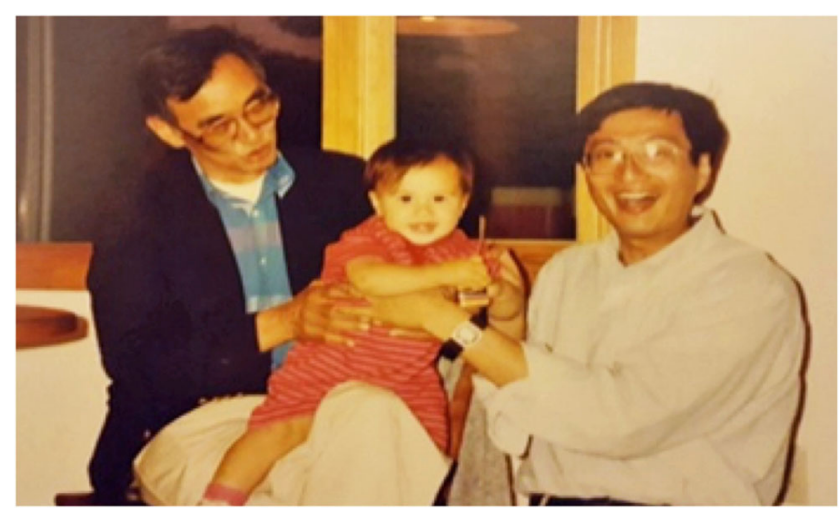

Figure 6. Gordon Sato with Jun and Sarah Hayashi.

laboratory developed early on the anti-EGF receptor monoclonal antibody that was to become cetuximab, paving the way for more anti-receptor antibodies to be developed. Gordon was a lifelong gardener and his view of science was like his view of a garden: what he did to all the generations of scientists that came after him was to provide the shovels and the fertilizer to dig deeper and allow science to provide more bounties. He not only was a brilliant scientist, but he made a difference in so many lives. I miss not being able to talk to Gordon Sato and seeing him come to A\&G, eager to tell him about the latest news about GP88. Even though he is no longer among us, Gordon is and will remain my lifelong inspiration.

\section{At the Foot of the Master: Experience with Gordon Sato 1975-1993 by Wallace L. McKeehan}

"To teach is to change lives forever."-Anonymous

"A true teacher would never tell you what to do. But would give you the knowledge with which you could decide what would be best for you to do." - C. Pike, Sati

I have been asked by several journals to write a traditional academic tributary summary of Gordon Sato's career, particularly the Lake Placid Cell Science Center, Upstate Biotechnology (UBI), and the Manzanar Project part of it. Every time I sat down since his death earlier this year to give it serious thought it became apparent that any attempt to capture the full extent of his scientific and humanitarian contributions, the breadth of his influence on individuals, his intellect and vision, and pure selfless concern for the development of people from individuals to the global community, was impossible. Hopefully, these qualities will be conveyed through this 
somewhat self-serving essay of some highlights of my personal association with the man and the influence he had on not only the technical aspects of my scientific thinking and career development, but more importantly the development of personal philosophy, character, morality, how to dissect the good from the evil in people, and generally how the world works and how to negotiate it. If there is one wish I would have for every young person with undeveloped potential and a sincere desire for it to unfold but who is in need of a jumpstart, it would be to come under the influence at least once, even for a short time, of a Gordon Sato (Fig. 7).

I first met Gordon on a visit he made from UC-San Diego to Richard (Dick) Ham's research group at the University of Colorado-Boulder in the late 1970s, which I had joined as a visiting scientist to learn cell biology after becoming bored with biochemistry and molecular biology. Dick and Gordon, both Caltech graduates, were overlapping postdoctoral researchers with Ted Puck in Denver, and both intellectually diverged from the Puck "cultured mammalian cells as microorganisms" thinking to consider using mammalian cells to mimic in vitro their complicated biology in vivo. Dick, as was I, was originally trained in the Roger Williams school of "nutritional and biochemical individuality," and thus we emphasized mimicking in the test tube the unique nutritional environment of diverse mammalian cells in vivo. It did not

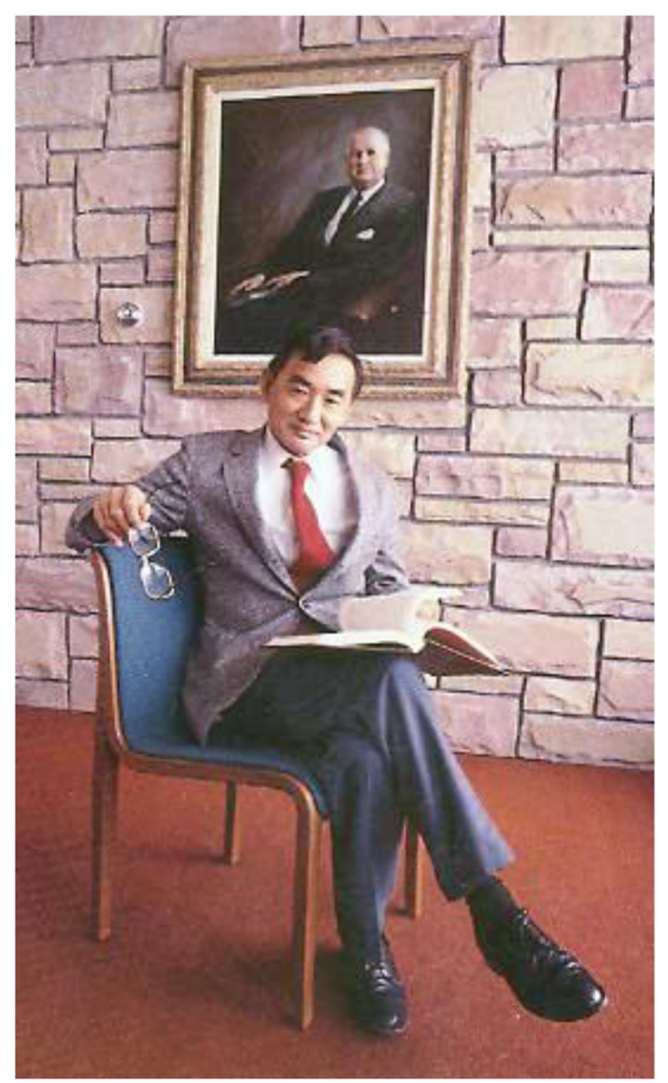

Figure 7. Gordon Sato in the Cell Science Center, portrait W. Alton Jones. go unnoticed at that visit where Gordon first introduced to us his contention that hormones and growth factors, some known, many yet to be discovered, were the key to mimicking the complex regulatory environment in vivo with cultured cells in vitro. However, as I was, in hindsight, a naïve but sincere and excited researcher eager to explain his new discoveries and the importance of nutrients and trace elements on new cell types in culture, Gordon hardly got a word in edgewise. Gordon was not one to suffer insincere and ignorant fools and those with self-aggrandizing and even malignant motives. He had a unique skill of distinguishing naïve enthusiasm from the ability for rational and critical thinking with potential to learn and develop that was worth his attention. Exhibiting a strong faith in logic and scientific thinking to quietly get his points across and influence others, not once did I witness him openly raise his voice in impatient frustration or anger over a particularly naïve opinion or interruption. Although once he tolerantly shook his head in response to a particularly enthusiastic argument, he obviously disagreed with and replied "OK, OK, stay on the track, keep probing, keep thinking, you will eventually understand." More commonly, he would sit quietly in his classic pose, one hand on chin, pipe in the other, and legs crossed, as if pondering your every word and how it fit into his universal visions. Gordon was a patient listener giving the impression that what you were saying, however naïve and limited, was important, that you were important.

From that first meeting, my developing career and personal world view became increasingly influenced by Gordon and eventually intimately intertwined with his vision for the W. Alton Jones Cell Science Center in Lake Placid, NY, the extension of his unique vision for an altruistic for-profit biotechnology in Upstate Biotechnology, Inc. (UBI), and his even larger global humanitarian vision in the Manzanar Project. This went far beyond guiding the direction of my laboratory research focus influenced by his pioneering concepts in understanding fundamental regulatory cell biology using cultured cells as the experimental tool. Through the experience from the years 1981 through 1993, I gained an insight into the multi-faceted genius, vision, and sheer unselfish goodness of personality of the man Gordon Sato that could fill volumes while I benefitted greatly from them.

In 1980 while a faculty member of the W. Alton Jones Cell Science Center, Lake Placid (Fig. 8), originally administered by the Tissue Culture Association (now Society for In Vitro Biology), and where my research theme converged with the emergent field in which Gordon was the leader and pioneer, I was overjoyed when asked by members of the W. Alton Jones family and friends my opinion of this man from UC-San Diego as a potential advisor and even director to the Cell Center. Then, I became further surprised and excited when Gordon asked me in passing what I thought of these Jones people and the potential future of the Cell Center. The defining 
Figure 8. W. Alton Jones Cell Science Center, Lake Placid, NY.

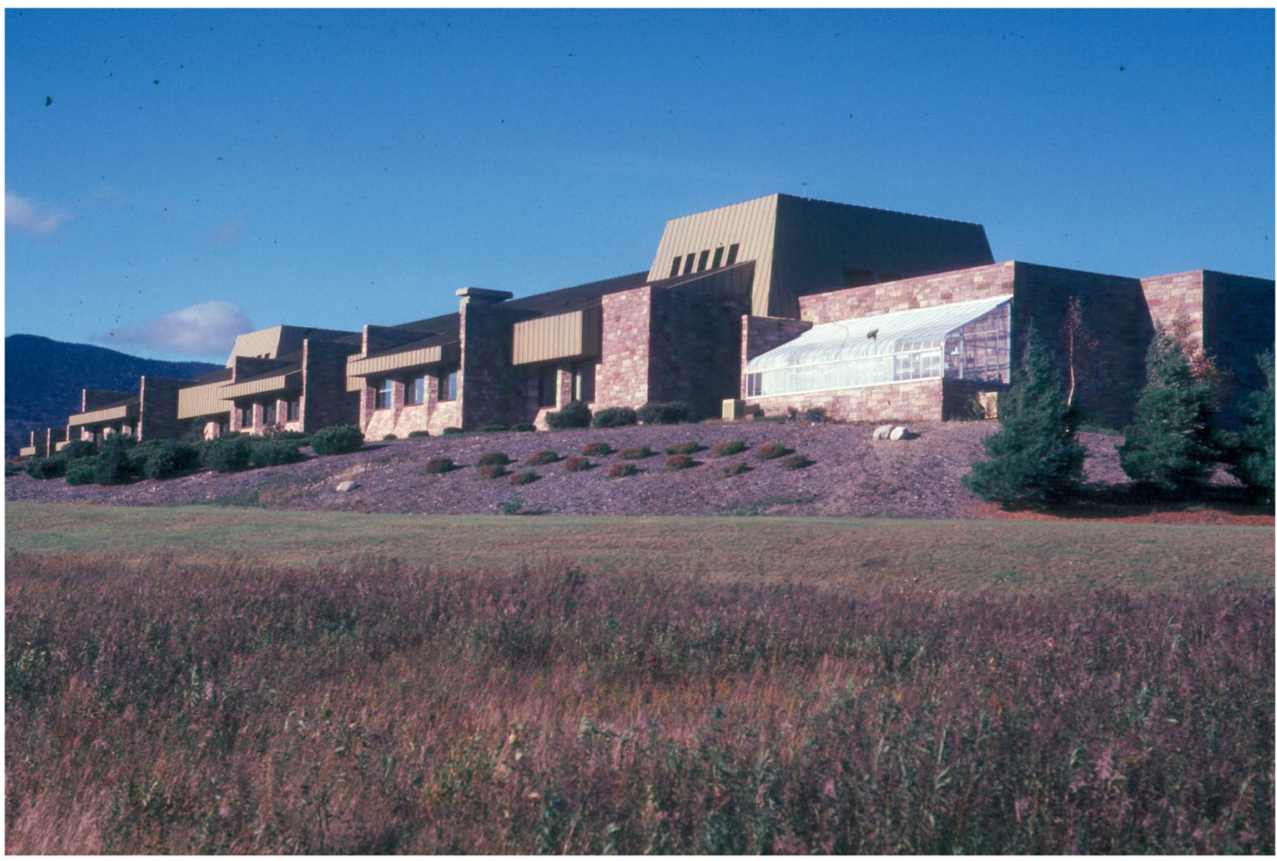

night was as I recall February 13, 1981 at the home of retiring director Paul Chapple, landmarked in my memory because of the birth the next morning of my daughter Maria during one of the coldest Adirondack winters on record. Present was a host of dignitaries, both friends of the Jones family, prominent scientists and Gordon. Among them was the Nobel Prizewinner James Watson who the Jones bunch were courting also as an advisor and potential director of the Center. Instead of catering to the Joneses for their financial resources, Gordon in his quiet usual logical and convincing way spent his effort outlining his long-term vision one on one, without regard to specifics of how or from where resources would come. Gordon was a reluctant administrative leader. To my knowledge, he never campaigned for position or power, but because of his quiet convincing vision and logic, he was drafted by those who could recognize and appreciate his vision and example. Those who could not appreciate his vision fell by the wayside and sometimes became resentful active opponents. He accepted administrative positions with reluctance and only when convinced that the accompanying authority would allow him to improve the welfare and development of individuals and to implement aspects of his vision. Three such positions were the president of the Tissue Culture Association (TCA), editor of its journal In Vitro, and director of the Cell Science Center. Gordon was not one to deal with the details of an administrative leadership position and sometimes let administrative minutia evolve a life of their own to a fault before finding the right person to delegate them to.

Gordon's promotion of individual personal development through evolution and experience was consistent throughout his educational roles as an academic professor and research group leader in training scientists, in his administrative positions, his biotechnology ventures, and the Manzanar Project. Although a risk taker on investing resources in and presenting individuals with opportunity, he had an uncanny ability to recognize hidden potential for personal development in individuals when it was least apparent to others. Due to his optimistic faith in the good in individuals, he was less adept at spotting early on hidden insincerity, pretense, arrogance, overconfidence, greed, and intolerance, sometimes to his detriment. But once perceived, Gordon's rare exhibition of prejudice and intolerance was when he perceived these characteristics in people and decided they were no longer worth his investment of time and resources. Gordon's emphasis was on the progress and development of individuals at all levels, and in all individuals, he had great faith in the triumph of the good versus the evil in them, sometimes to a fault. His greatest pride was in the progress of individuals that came under his influence and his greatest disappointment those he had faith and investment in that yielded to the corruption, bribes, and pressures of those who resented his vision and efforts.

I was fortunate to be one of those shy, insecure, and full of self-doubt individuals that Gordon not only schooled at the research group leader/professor stage of my scientific career, but threw me into the harsh world of administration and service as his surrogate on the board of the TCA, associate editor of the journal In Vitro, associate director of the Cell Science Center, and co-founder, first president/CEO, and board member of UBI.

Gordon had a unique philanthropic vision for the profits from biotechnology business ventures through technology transfer that exhibited his global view that the fruits of an individual's labor should return directly back to the individual while contributing to development of as many other 
Figure 9. Gordon Sato with the McKeehan Lab Group, Lake Placid, NY.

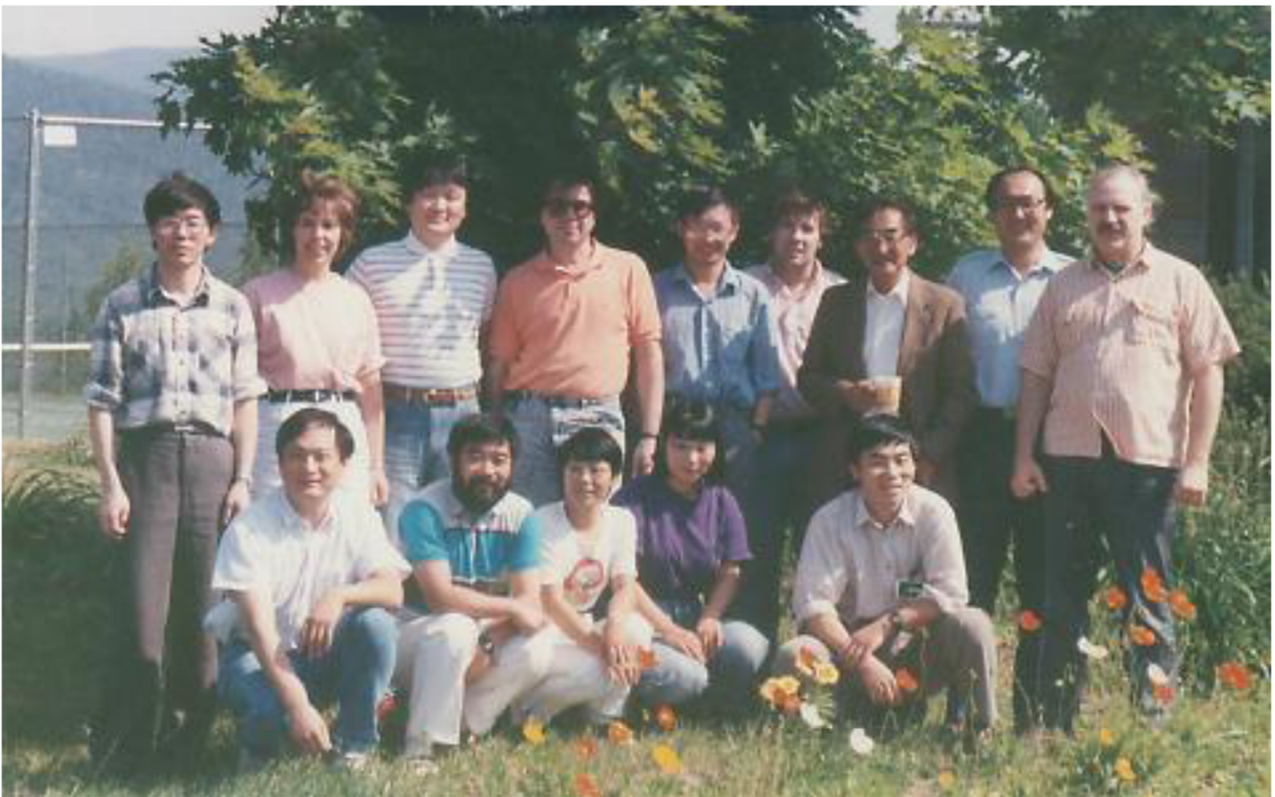

individuals as possible. One of his earliest ventures was through the appropriately named Collaborative Research, Inc. The organization was a vehicle for distributing recently discovered hormones and growth factors from the laboratories of the discoverer at lowest cost possible to the broader community, reagents of great utility in frontier research that would otherwise be impossible to produce. The discoverer, who was the single most capable producer of the intrinsically qualitycontrolled reagent used in daily experimentation, received compensation for the product to support his or her continued research program. This concept took the form of numerous similar ventures specializing in emergent frontier cell biological discoveries. Gordon continuously used these biotechnology transfer ventures as a platform for education and training of individuals, both in the technical and organizational aspects of the business. Multiple generations of his students and associates have combined academic research with stellar careers in cell biotechnology, many by establishment of their own independent ventures through implementation of unconventional and novel approaches he passed down to them.

At the Cell Science Center in Lake Placid (Fig. 9), Gordon ramped this philanthropic vision up to a new level. This was the idea that the same profit sharing concept with minimal overhead and administration could be expanded to liberate the individual researchers of the entire institute from nonproductive individual fundraising and demands of bureaucracy to focus purely on frontier discoveries and intellectual pursuits. No doubt influenced by his stint in such an institute, the LaRoche-supported Basel Institute for Immunology in Switzerland, he envisioned such an idealistic institute in the beautiful Adirondack Mountains that would also be a base for his emergent vision on global humanitarian development, the Manzanar Project. Upstate Biotechnology, Inc. (UBI) began in Gordon's usual manner of recruitment of people to help execute his ideas that on paper were least qualified or even interested. With Gordon, it was a thin line in whether he had full confidence in you from the start, or it was an initial test to see your reaction to judge if you were worth his investment of time in you. At a time when I had little interest in diverting my time from the lab bench, with little background information, Gordon laid the original legal incorporation agreement for UBI on my desk and said, "Name this new biotech company, I'll explain it later." Without much thought and interest at the time, driving by outside the office window was the truck that serviced the institute vending machine with the big letters "Upstate Vending Co." Within the hour began "Upstate Biotechnology, Inc." with my short-lived appointment as its first president and CEO. Our first products were EGF and antibodies to its receptor pioneered by Gordon and his son Denry, and organ extracts enriched in various forms of FGF developed in my laboratory.

Perhaps the most dramatic personal educational experience Gordon thrust on me was integration with the development and evolution of UBI. Gordon's vision was a radical concept for the period in which a non-profit research institute (W. Alton Jones Cell Science Center) would be supported and endowed from profits of a for-profit entity (UBI) solely owned and for the benefit of the non-profit research endeavor. The evolution of UBI was living proof of the adage: A unique new idea is first ignored, even resisted, by those without an ability to think of it on their own, as it unfolds it triggers the skeptics attention, and as it becomes successful and proven (in the case of UBI profitable), the skeptics adopt it, steal it, and then claim it as their own. As Gordon's confidant and sounding board, second only to perhaps Josette Gaudreau, I witnessed intimately Gordon's steady intellect and reasoning power, purity 
of motive and character and absence of personal malice, his eternal optimism, and honest altruistic motives in attempts to maintain the idea and vision. In stark contrast during the experience, I witnessed the darkest elements of personal greed, lack of ethics, arrogance and abuse of power, and lack of vision and concern for individuals going under the façade of philanthropy and altruism, as the mission of UBI was subverted into personal profits and agendas of others. Coincident was the eventual dismantling of the non-profit research entity itself, turning it into a personal agenda profitmaking entity in conflict with the original charter, and destruction of the vision of a self-sustaining "Rockefeller University in the Adirondacks."

During this period, the teacher and "guru" Gordon Sato imparted a personalized educational experience far beyond the mechanics of managing a research group, an institute, and biotechnology endeavor. For here from him I learned a great deal about how the world works, the stark contrast between good and evil in individuals, abuse of power and privilege over the weak, honest altruism, and how to negotiate and get along in such a world without ethical compromise. More than once suddenly during an intense impromptu strategy session to discuss developments, sometimes called in the middle of the night, often with Josette G. and perhaps another confidant, calmly pondering in his usual "guru" pose with us students at his feet, legs crossed and puffing on his pipe, always using the scientific method, if plan A, then what, if plan B, then what, he would blurt out "McKeehan, are you learning anything from all this?"

Gordon's approach to formal education of individuals in science, both in cell biology and later in the Manzanar Project, was always unconventional, innovative, and often targeted toward individuals whose development was inhibited by cultural and economic background. Here, he had a firm belief that education and development of these individuals would have the most impact of his efforts and would result in the highest level of self-motivation and success. No doubt because of familial affinity, he took a large interest in nurturing visiting scientists from Japan and through his influence on them injecting conceptual innovation, original thinking, and change into a Japanese science culture largely based on copying the ideas of others. He has many former associates who are in leadership positions in Japanese academics, biotechnology, and medicine who adopted his philosophy. In the early 1980s, he recognized the vast potential in Chinese students and visiting scientists unleashed by the Deng Xiaoping Open Door Policy. He personally recruited trainees during visits to major Chinese universities to join the Cell Science Center in Lake Placid. To be able to award an accredited Ph.D., Gordon established a collaborative graduate program with Clarkson University, Potsdam, NY, in which formal course work was done both in Clarkson and Lake Placid, and the thesis research work was done in Lake Placid laboratories. Many who arrived

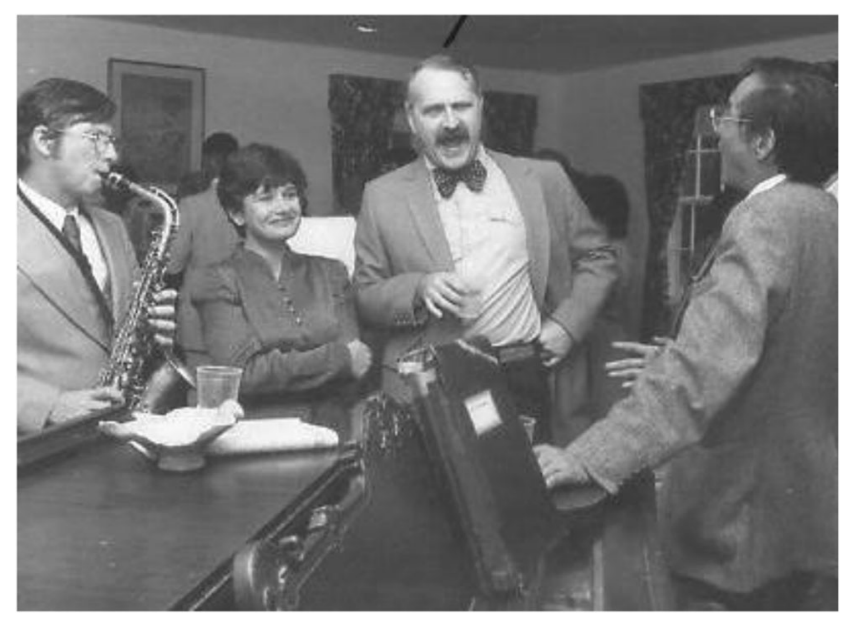

Figure 10. Singing together at a board meeting social.

in Lake Placid with $\$ 100$ or less are successful professionals in science and biotechnology both in the USA and China and are giving rise to multiple generations of trainees trained in the Sato method as they were.

Gordon's concern for the development and welfare of individuals and their families was limitless. He provided temporary housing and dormitories for students and apartments for visiting scientist families by purchasing ski lodges in the otherwise resort town of Lake Placid. These became gathering and sometimes community cooking places during breaks from lab work. He provided transportation for students to attend classes at the 50 miles distant Potsdam at Clarkson in the sometimes $-40^{\circ}$ winter days in Lake Placid. Gordon did everything he could to ease the shock of foreign students and associates once they realized that Lake Placid, NY (population 2500) was not New York City. He loved to cook for others, particularly Oriental cuisines, the materials of which were particularly sparse in Lake Placid. He organized a supply line of raw materials on his travels and sponsored routine runs for supplies to Montreal ( $2 \mathrm{~h}$ away). He organized a low-cost "lunch club" featuring oriental fare which became a gathering

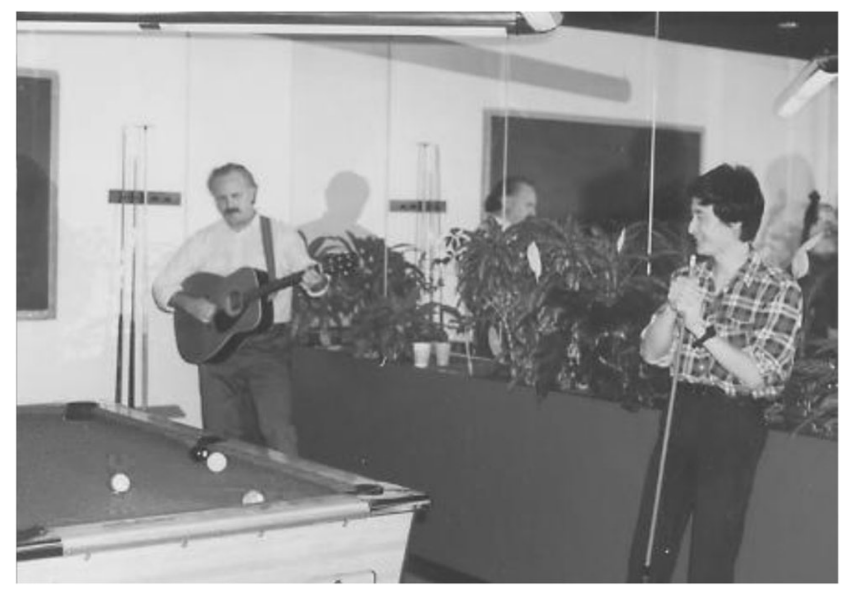

Figure 11. Lunchtime in the institute recreational room. 


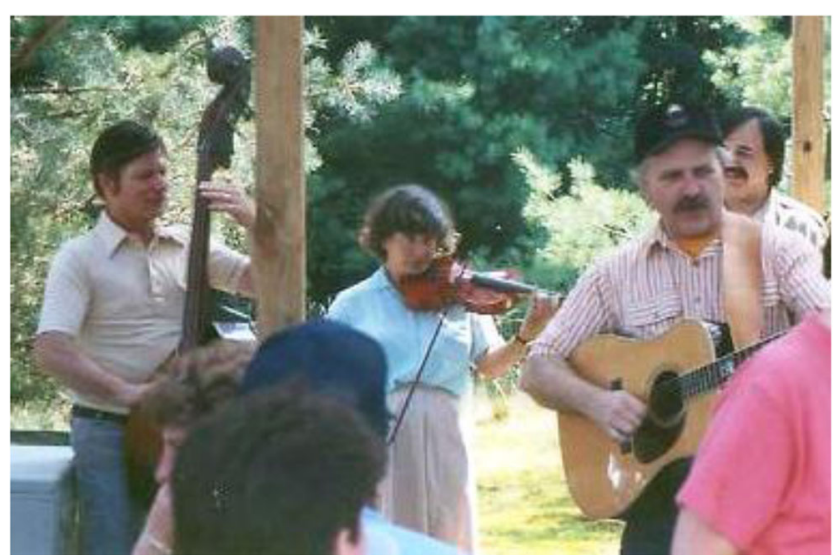

Figure 12. Picnic on the Cell Center grounds in Lake Placid.

place sometimes with music performed by staff that varied from folk, jazz, and country western to classical. On rare occasions, this included Gordon himself on his familiar saxophone (Figs. 10, 11, and 12).

Gordon used innovative ways to bring families together and integrate them into his programs, both in the research and teaching programs as well as extracurricular activities. He showed great interest in the spouses and children of staff. His philosophy was that a happy family was the most productive. He united numerous spouses and children of primary appointees on the scientific staff, both students and visiting scientists, often through providing them employment in assisting their spouses or integrating them into the community through volunteer activities (Fig. 13). As an avid gardener from his youth, he made the barren landscape of the Cell Center blossom and often was seen tending the grounds along with the institute maintenance staff or simply puttering in the flowerbeds outside his office. Consistent with his overall philosophy of nurture and culture of plants as well as individuals, his favorite song was The Garden Song by David Mallett (lyrics appended). He insisted we sing it at all gatherings when occasion arose (Fig. 14).

He provided the staff with gardening plots to grow their own vegetables on the grounds of the director's residence. He built a tennis court on the Cell Center grounds; a signature tennis racket was part of Gordon's person as much as a briefcase.

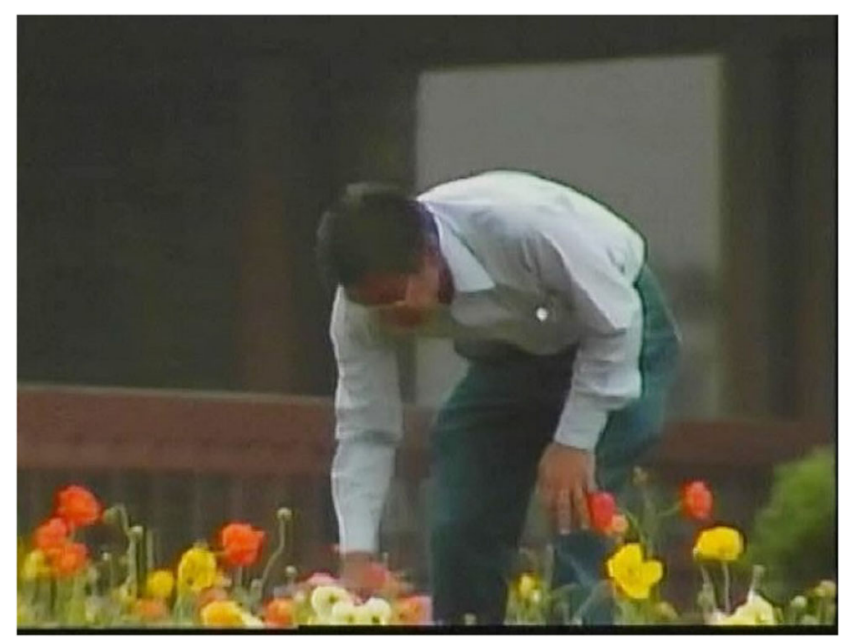

Figure 14. Gordon tending Cell Center poppies.

Along with that, he installed a massive telecommunication satellite dish to provide staff with access to worldwide cable news and entertainment as well as a pool table, ping pong table, piano, and other musical instruments in the lunch room.

Gordon not only inspired and admired dedication and persistence to achieve the specific result, whether in the laboratory, discussions, or other venues, he had a strong belief that science should be fun and enjoyable. He seemed to take pride in breaking down formality and even shocking the inexperienced with some new exotic food or unusual experience. Sometimes, I thought that this might be part of his global vision of educating by experience or testing one's tolerance or bias. He seemed to always have in his briefcase or hotel room some exotic oriental snack complete with chopsticks as well as a bottle of wine or sake to go along with a postevent discussion session into the wee hours of the night. One time at a TCA meeting in New Orleans when Gordon was a president of the organization, after a tedious board meeting in the hotel, he suggested we continue the meeting down in a French Quarter oyster bar, but not before taking the entire board into an exotic stage show which obviously was shocking to some of the members. Institutional social events with Gordon always included some unusual source of entertainment, usually

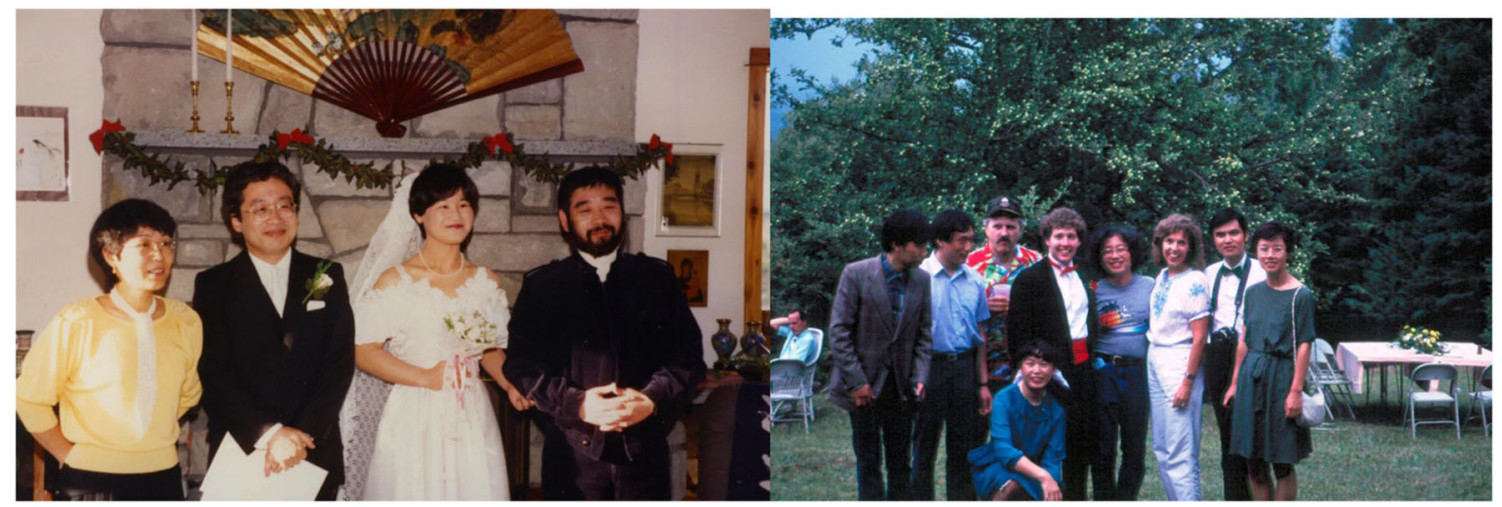

Figure 13. Cell Center weddings. 
music with audience participation, sometimes impromptu with amateur staff, sometimes more skilled and professional.

Gordon's firm belief in rational thinking and the scientific method as the solution to mankind's problems underpinned his vision for a self-sustaining extended family and community living an entire dedicated lifestyle as a training ground for independent and innovative thinking in the peaceful setting of the Adirondack Mountains. For its 10-yr life under his influence, the Lake Placid Cell Science Center results of individual development now spread through several generations of scientists throughout the world is unprecedented albeit unheralded. The specific research contributions of high impact united under the common theme of cellular endocrinology in vitro that emerged from the research groups are also remarkable.

Gordon's unwavering belief that rational thought and the scientific method could eventually triumph over ignorance, evil, poverty, and suffering was ramped up to a new level with the Manzanar Project which began in Lake Placid and dominated the last years of his active life. The project in all its ramifications in theory and practice and its numerous awards and recognition could fill a volume on its own and is beyond the scope of this essay. I was privileged to witness its earliest conceptual development from his ideas on biological food chains supported by salt water deserts begun at the Salton Sea while he was still at UC San Diego to his field projects around the world that eventually found success in Eritrea (Fig. 15). In his global vision, the Lake Placid center in addition to its role as a training center for high tech research and biotechnology would also be an administrative training base for implementation of the worldwide mission of the Manzanar Project aimed at alleviating hunger and building a supportive economy in the world's poorest populations through low-tech biotechnology applied in salt water deserts. Gordon's approach to education and development of individuals by planting the seeds that allowed them to raise themselves by their own bootstraps unfolded in its extreme in Eritrea and especially a small village named Hergigo which built their modest economy through mangrove forests in salt water. The Hergigo experiment is on record as a success and serves as proof of concept of the idea and vision. Like his endeavors in cell biology and biotechnology, there are numerous individuals in their native lands that were touched by Gordon to carry on the vision. The Manzanar Project exhibited the extreme depth of the man Gordon Sato's character, consistency, his love for his fellow man, and passion for solving the world's most critical problems through science and technology transfer.

Gordon valued simplicity, freedom, and responsibility of the individual to find their own way and was a firm believer in learning by experience rather than theory. He had a disdain for bloated bureaucracy and administration and fought its disproportionate drain on resources for seeding the direct mission. He was a firm believer in the corrupting nature of unearned resources and welfare both to individuals and institutions. Coincident with this was the belief that individuals and communities like Hergigo should be the direct recipients of their development efforts without confiscation of a proportion of their efforts for unproductive bureaucracy.

Despite the injustice he experienced in his early incarceration in the Manzanar concentration camp, the hijacking and subversion of his vision and efforts for UBI and the Lake Placid Cell Science Center by arrogance and abuse of power and privilege from elitist elements and their cronies based in Charlottesville, and the political corruption of government officials in third world countries he encountered in the Manzanar Project, I never witnessed an element of hate, bitterness, or defeat in his attitude. Such hurdles seemed to drive him on to new ideas on how rational thinking, basic morality, and science could overcome injustice. Gordon was the eternal optimist in his devotion to science as the long-term answer to overcoming humanity's most critical problems threatening injustice and even self-destruction caused by the dark or evil side of human nature.

Although Gordon is gone and those of his kind seem fewer and fewer as time goes on, the Gordon Sato philosophy and approach lives on through the many individuals and their descendants in science that he influenced. Around the world, whether the USA, Europe, Japan, China, and Africa with a little background information and examination of their
Figure 15. Gordon with villagers of Hergigo, Eritrea.

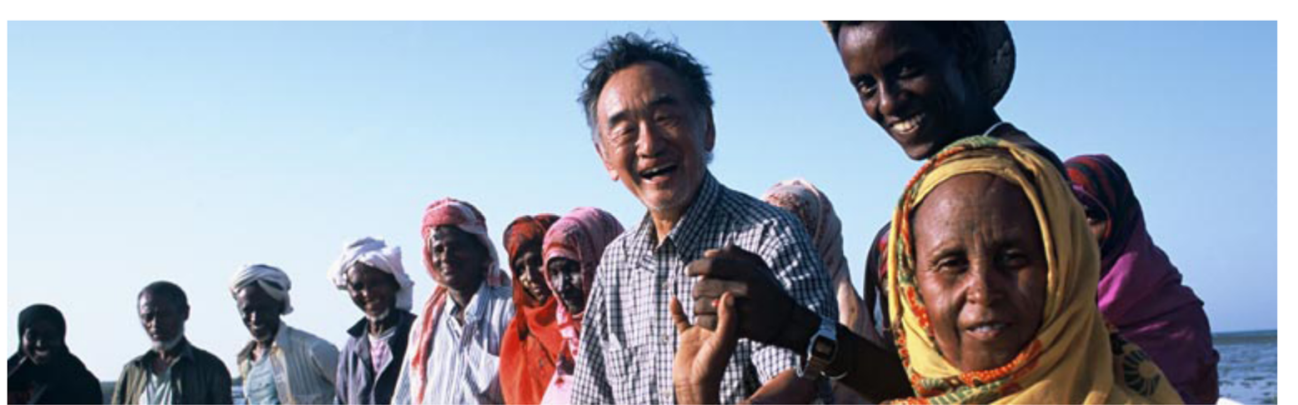


approach to science, there is something common and special about a Gordon Sato student - a love of life, good food and drink, rugged individualism, devotion to logic and rational thinking, a love of science, and general optimism about the future of humanity.

Online Background Links:

Gordon Sato-Wikipedia: https://en.wikipedia.org/wiki/ Gordon_H._Sato

The W. Alton Jones Cell Science Center-Wikipedia: https:// en.wikipedia.org/wiki/The_W._Alton_Jones_Cell_Science_ Center

The Manzanar Project: Low Tech Solutions to Hunger and Poverty: http://themanzanarproject.com/

Lyrics to The Garden Song by David Mallett:

Inch by inch, row by row

Gonna make this garden grow

All it takes is a rake and a hoe

And a piece of fertile ground

And inch by inch, and row by row

Someone bless these seeds I sow

Someone warm them from below

Till the rain comes tumblin' down

And pullin' weeds and pickin' stones

Man is made of dreams and bones

Feel the need to grow my own

'Cause the time is close at hand

And rain for grain, sun and rain

Find my way in nature's chain

And tune my body and my brain

To the music from the land

Inch by inch and row by row

Gonna make this garden grow

All it takes is a rake and a hoe

And a piece of fertile ground

And inch by inch, and row by row

Someone bless these seeds I sow

And someone warm them from below

Till the rain comes tumblin' down

Plant your rows straight and long

Temper them with prayer and song

And mother earth will make you strong

If you give her love and care

An old crow watchin' hungrily

From his perch in yonder tree

And in my garden I'm as free

As that feathered thief up there

Inch by inch and row by row

Gonna make this garden grow

All it takes is a rake and a hoe

And a piece of fertile ground

And inch by inch, and row by row

Someone bless these seeds I sow

And someone warm them from below
Till the rain comes tumblin' down

Writer: David Mallett

Acknowledgments T.O. was supported by Grant-in-Aid for Scientific Research (B) (Grant Number 24390456) from the Japan Science Promotion Society.

Open Access This article is distributed under the terms of the Creative Commons Attribution 4.0 International License (http:// creativecommons.org/licenses/by/4.0/), which permits unrestricted use, distribution, and reproduction in any medium, provided you give appropriate credit to the original author(s) and the source, provide a link to the Creative Commons license, and indicate if changes were made.

\section{References}

Augusti-Tocco G, Sato G (1969) Establishment of functional clonal lines of neurons from mouse neuroblastoma. Proc Natl Acad Sci U S A 64:311-315

Barnes D, McKeehan WL, Sato GH (1987) Cellular endocrinology: integrated physiology in vitro. Vitro Cell Dev Biol 23:659-662

Barnes D, Sato G (1980) Methods for growth of cultured cells in serumfree medium. Anal Biochem 102:255-270

Barnes D, Sato G (1981) Serum-free cell culture: A unifying approach. Cell 22:649-655

Benda P, Lightbody J, Sato G, Levine L, Sweet W (1968) Differentiated rat glial cell strain in tissue culture. Science 161:370-371

Buonassisi V, Sato G, Cohen AI (1962) Hormone-producing cultures of adrenal and pituitary tumor origin. Proc Natl Acad Sci U S A 48: 1184-1190

Cuprak LJ, Sato GH (1968) Nutritional requirements of mouse adrenal cortex tumor cells in culture. Cell Res 52:632-645

Fisher HW, Puck TT, Sato G (1958) Molecular growth requirements of single mammalian cells: The action of fetuin in promoting cell attachment to glass. Proc Natl Acad Sci U S A 44:4-10

Fisher HW, Puck TT, Sato G (1959) Molecular growth requirements of single mammalian cells. III. Quantitative colonial growth of single $\mathrm{S} 3$ cells in a medium containing synthetic small molecular constituents and two purified protein fractions. J Exp Med 109:649-661

Gospodarowicz D, Jones K, Sato G (1974) Purification of a growth factor for ovarian cells from bovine pituitary cells. Proc Natl Acad Sci U S A 71:2295-2299

Hayashi I, Sato G (1976) Replacement of serum by hormones permits the growth of cells in a defined medium. Nature 259:132-134

Masui H, Kawamoto T, Sato JD, Wolf B, Mendelsohn J, Sato G (1984) Growth inhibition of human tumor cells in nude mice by anti-EGF receptor monoclonal antibodies. Cancer Res 44:1002-1007

Mohit B, Sato GH (1967) Improved in vitro survival of normal, functional spleen cells. Science 157:449-451

Nishikawa K, Armelin HA, Sato GH (1975) Control of ovarian cell growth in culture by serum and pituitary factors. Proc Natl Acad Sci U S A 72:483-487

Rosenthal MD, Wishnow R, Sato GH (1970) The in vitro growth and differentiation of clonal populations of multipotential mouse cells derived from a transplantable testicular teratocarcinoma. J Natl Cancer Inst 44:1001-1014

Sato G, Augusti-Tocco G, Kelly P, Posner M (1970) Hormone-secreting and hormone-responsive cell cultures. Recent Prog Horm Res 26: 539-545

Sato G, Zaroff L, Mills SE (1960) Tissue culture populations and their relation to the tissue of origin. Proc Natl Acad Sci U S A 46:963972 
Sato GH (1956) Activation of bacteriophage by urea. Science 123:891892

Sato GH (1981) Antibodies, hormones and cancer. In: Steinberg CM, Lefkovits I (eds) The immune system, vol I. S. Karger, Basel, pp 379-382

Sato GH, Fisher H, Puck TT (1957) Molecular growth requirements of single mammalian cells. Science 126:961-964

Sato JD, Kawamoto T, Le AD, Mendelsohn J, Polikoff J, Sato GH (1983) Biological effects in vitro of monoclonal antibodies to human EGF receptors. Mol Biol Med 1:571-579

Shinohara K, Zhao Y, Sato GH (1984) Selective procedures for the mass culture of blue-green algae in the desert. In: Downey K, Ahmad F,
Schultz J (eds) Advances in Gene Technology: Molecular Genetics of Plants and Animals. Miami Winter Symposium, Miami Beach, vol. 20, pp 327-332

Stollar V, Buonassisi V, Sato G (1964) Studies on hormone secreting adrenocortical tumor in tissue culture. Exp Cell Res 35:608-616

Tashjian AH Jr, Yasumura Y, Levine L, Sato GH, Parker ML (1968) Establishment of clonal strains of rat pituitary tumor cells that secrete growth hormone. Endocrinology 82:342-352

Yasumura Y, Tashjian AH Jr, Sato GH (1966) Establishment of four functional, clonal strains of animal cells in culture. Science 154: 1186-1189 